\title{
Preliminary Evaluation of the teaching of Homeopathy in undergraduate Pharmacy Courses in Brazilian states Paraná and Santa Catarina
}

\author{
Susan Andreise Cipriano Baracho', Karen Denez ${ }^{2}$, \\ Javier Salvador Gamarra Junior ${ }^{1}$
}

(1) Campos de Andrade University, Uniandrade, Curitiba, Paraná, Brazil, (2) Brazilian Association of Homeopathic Pharmacists - ABFH, Santa Catarina, Brazil

\begin{abstract}
Introduction: Homeopathy and other integrative and complementary health practices were included in the Brazilian public health system (SUS) under a formal policy established by the Health Ministry in 2006 [1]. This led to an increase in the demand of homeopathic assistance, not accompanied by a corresponding increase in human and material resources [2,3,4]. On the other hand, an evaluation of market demands carried out by the Education Ministry (MEC) in 2000 led to a reform of the syllable of undergraduate pharmacy courses, which thus included formal teaching of homeopathy [2].

Aims: To make a preliminary quantitative and qualitative evaluation of the teaching of homeopathy in undergraduate pharmacy courses in Brazilian States Paraná and Santa Catarina as to the establishment of a formal discipline, academic credits and the qualification of professors.

Methods: The MEC Internet database was surveyed looking for universities with undergraduate courses in pharmacy and their study programs were screened online as to the inclusion of formal teaching of homeopathy. Deans and professors were sent a semi-structured questionnaire adapted from the model developed by the Brazilian Association of Homeopathic Physicians (ABFH) [5]. Questions sought to assess the formal institutionalization of the teaching of homeopathy (categories, credits) and the qualification of professors. This study was approved by the Research Ethics Committee of Uniandrade (Process No. 316/2009).

Results: 25 schools in Paraná (PR) and 12 in Santa Catarina (SC) have undergraduate courses of pharmacy. Four schools in PR were excluded from this study because they do not exhibit data online and no questionnaires were returned. From the remaining 21, 20 (95.2\%) include homeopathy in their study program and $6(28.6 \%)$ returned questionnaires. In SC, 1 school exhibits no data and 1 school does not include homeopathy in its study program, the remainder 10 (83.3\%) do and 4 returned questionnaires. As a whole, from the initial sample, 30 schools include homeopathy and one does not; 10 questionnaires were returned. The overall credits of pharmacy courses measured in hours are 3,760-5,157 ( 4,458) in PR and 3,096-4,968 $(\sim 4,217)$ in SC. The discipline specifically devoted to homeopathy is named in different ways, the most frequent term used is "homeopathic pharmacotechnics" ( $\mathrm{PR}=8, \mathrm{SC}=6)$. Its corresponding credits are 36-136 ( 72.4) in PR and 32-72 ( 57.6) in SC. In PR in 1 school (5\%) and in SC in 2 schools (20\%) homeopathy is optional, in all other cases is mandatory. All professors $(n=10)$ teaching homeopathy are pharmacists, 5 hold a MA and 3 a PhD degree, 3 are board certified; 7 have specific raining in homeopathy, whereas 3 do not.
\end{abstract}


Conclusions: Homeopathy has been included in almost all pharmacy undergraduate courses in PR and SC. In most schools, credits measured as hours is adequate (minimum required $=60 \mathrm{~h}$ ). However, a wider availability of courses and teachers with better qualifications are still needed.

Keywords: Evaluation; Undergraduate: Pharmacy: Homeopathy; Teaching

\section{References}

[1] BRASIL. Ministério da Saúde. Secretaria de Atenção à Saúde. Departamento de Atenção Básica. National Policy of Integrative and Complementary Practices in the Unified Health System - SUS. Ministério da Saúde, Secretaria de Atenção a Saúde, Departamento de Atenção Básica. -Brasília: Ministério da Saúde; 2006, 92 p.

[2] Corrêa AD, Leite SQM. The teaching of homeopathy in pharmacy undergraduation: pedagogical conceptions and practices in institutions from the state of Rio de Janeiro. Interface - Comunic, Saúde, Educ 2008 Apr-Jun; 12 (25):267-280.

[3] Santanna C, Hennington EA, Junges JR. Homeopathic care and the principle of integrality. Interface Comunic, Saúde, Educ 2008 Apr-Jun; 12(25):233-246.

[4] Galhardi WMP, Barros NF. The teaching of homeopathy and practices within Brazilian Public Health System (SUS). Interface - Comunic, Saúde, Educ 2008 Apr-Jun; 12(25):247-266.

[5] Denez K. O perfil do ensino de homeopatia nos cursos de graduação em farmácia: um estudo parcial. In: VIII Simpósio Nacional e VIII Encontro Internacional de Pesquisa Institucional em Homeopatia; 2004 May 20-22; São Paulo, Brazil. São Paulo: p. 33.

\section{Avaliação preliminar sobre o perfil do ensino da Homeopatia nos cursos de Farmácia dos estados do Paraná e Santa Catarina}

\section{RESUMO}

Introdução: Homeopatia, junto a outras práticas integrativas e complementares em saúde (PIC) foi implementada no Sistema Único de Saúde brasileiro (SUS) por meio de política pública do Ministério da Saúde (MS) em 2006 [1], com consequente aumento da demanda e percepção da falta de profissionais capacitados, gerando problemas de acesso ao serviços, com destaque à assistência farmacêutica homeopática [2,3,4]. Ministério da Educação brasileiro (MEC) avaliou o Mercado em 2000 e determinou aos cursos de graduação em farmácia ajustes nas grades curriculares incluindo homeopatia na formação [2].

Objetivos: Fazer avaliação preliminar do ensino da homeopatia nos cursos de graduação em farmácia nos Estados do Paraná e Santa Catarina. Fazer avaliação quantitativa e qualitativa considerando oferta da disciplina/campo na graduação, carga horária ofertada, capacitação docente.

Metodologia: Pesquisa aprovada no Comitê de Ética em Pesquisa da Uniandrade (Processo n. 316/2009). Foi feito levantamento no MEC (internet) para localizar IES com graduação em farmácia. O currículo das IES foi 
analisado via internet para verificar oferta ou não de homeopatia. Metodologia amostrou 25 Instituições de Ensino Superior do Paraná (PR1 a PR25) e 12 de Santa Catarina (SC1 a SC12) com curso de farmácia. Foi enviado aos coordenadores de curso e professores questionário semi-estruturado adaptado do modelo da Associação Brasileira de Farmacêuticos Homeopatas (ABFH) [5]. Questões incluíram condições da disciplina (carga horária, categoria), qualificação docente.

Resultados: Do Paraná ( $\mathrm{n}=25)$ quatro escolas foram excluídas por não terem dados nem por internet nem questionários respondidos. Oferecem homeopatia 20 escolas com dados na internet $(95,2 \%)$. Seis escolas responderam questionário $(28,6 \%)$. De Santa Catarina $(n=12)$ uma não oferta e uma não tinha dados. Das dez escolas com homeopatia (83,3\%), quatro responderam questionário. Da amostra inicial (PR e SC) 30 escolas ofertam, uma não. Sobre carga horária total de curso (h/a), PR variou de 3.760-5.157 ( 4.458), SC 3.096-4.968 ( 4.217). Sobre currículo generalista uma escola ainda não havia implantado. Disciplina recebe diferentes denominações, farmacotécnica homeopática $(\mathrm{PR}=8, \mathrm{SC}=6)$ mais frequente. Carga horária da disciplina (h/a) no PR (n=19) 36-136 ( 72,4). Em SC (n=8) 32-72 ( 57,6). Oferta de disciplina, PR (n=20), somente uma eletiva (optativa). Em SC $(n=10)$, duas eletivas $(20 \%)$, demais curriculares. Todos docentes farmacêuticos $(n=10)$, cinco mestres, dois doutores, três especialistas. Sete docentes capacitados, três não.

Conclusões: Inserção da homeopatia nas escolas de farmácia próxima de 100\%, maioria das escolas com carga horária ofertada adequada (mínimo exigido é $60 \mathrm{~h} / \mathrm{a}$ ). Necessidade de ampliar disponibilidade e capacitação docente.

Palavras-chave: Avaliação; Graduação; Farmácia; Homeopatia; Ensino

\section{(c)) BY-NC-ND Licensed to GIRI}

Support: authors declare that this study received no funding

Conflict of interest: authors declare there is no conflict of interest

Correspondence author: Javier Salvador Gamarra Junior, javiers@terra.com.br

How to cite this article: Baracho SAC, Denez K, Gamarra Jr JS. Preliminary assessment about homeopathy instruction in schools of pharmacy in states of Paraná and Santa Catarina, Brazil. Int J High Dilution Res [online]. 2011 [cited YYYY Month dd]; 10(36): 289-291. Proceedings of the XXV GIRI Symposium and VIII CBFH; 2011 Sep 04-07; Foz do Iguaçu (Brazil). GIRI and ABFH; 2011; Available from: http://www.feg.unesp.br/ ojs/index.php/ijhdr/article/view/509/521 